IZA DP No. 7168

Lessons Learned from the Largest Tenure Mix Operation in the World:

Right to Buy in the United Kingdom

Reinout Kleinhans

Maarten van Ham

January 2013 


\title{
Lessons Learned from the Largest Tenure Mix Operation in the World: Right to Buy in the United Kingdom
}

\author{
Reinout Kleinhans \\ Delft University of Technology \\ Maarten van Ham \\ Delft University of Technology \\ and IZA
}

\author{
Discussion Paper No. 7168 \\ January 2013
}

IZA
P.O. Box 7240
53072 Bonn
Germany

\author{
Phone: +49-228-3894-0 \\ Fax: +49-228-3894-180 \\ E-mail: iza@iza.org
}

\begin{abstract}
Any opinions expressed here are those of the author(s) and not those of IZA. Research published in this series may include views on policy, but the institute itself takes no institutional policy positions. The IZA research network is committed to the IZA Guiding Principles of Research Integrity.

The Institute for the Study of Labor (IZA) in Bonn is a local and virtual international research center and a place of communication between science, politics and business. IZA is an independent nonprofit organization supported by Deutsche Post Foundation. The center is associated with the University of Bonn and offers a stimulating research environment through its international network, workshops and conferences, data service, project support, research visits and doctoral program. IZA engages in (i) original and internationally competitive research in all fields of labor economics, (ii) development of policy concepts, and (iii) dissemination of research results and concepts to the interested public.
\end{abstract}

IZA Discussion Papers often represent preliminary work and are circulated to encourage discussion. Citation of such a paper should account for its provisional character. A revised version may be available directly from the author. 


\section{ABSTRACT \\ Lessons Learned from the Largest Tenure Mix Operation in the World: Right to Buy in the United Kingdom}

In the last few decades, urban renewal policies have taken firm root in many Western European countries. Underlying these renewal policies is a strong belief in negative neighborhood effects of living in poverty concentration areas, often neighborhoods with a large share of social housing. In Europe, great importance is attached to creating a more diverse housing stock (in terms of tenure and dwelling types) and as a means to establish a more socially mixed neighborhood population. Mixed housing strategies are stated explicitly by governments in the Netherlands, the United Kingdom, Germany, France, Finland and Sweden. The idea is that mixing homeowners with social renters will create a more diverse socio-economic mix in neighborhoods, removing the potential of negative neighborhood effects. By far the largest tenure mix operation in Europe is the Right to Buy (RTB) scheme in the United Kingdom. Since the 1970s, over 2.7 million social rented houses have been sold with large discounts, mainly to sitting tenants. In this paper we synthesize the outcomes of RTB with regard to neighborhood impacts: residualisation, neighborhood stability, tenure mix and social mix, social interactions, and dwelling maintenance. Although we acknowledge substantial socioeconomic benefits of the RTB for many individual residents, we find that the neighborhood outcomes of RTB are by no means solely beneficial.

JEL Classification: J61, R21, R23, R28

Keywords: Right to Buy, tenure mix, neighbourhood effects, urban renewal, residential mobility, poverty neighbourhoods

Corresponding author:

Reinout Kleinhans

Delft University of Technology

OTB Research Institute for the Built Environment

PO Box 5030

2600 GA Delft

The Netherlands

E-mail: r.j.kleinhans@tudelft.nl 


\section{Introduction}

In the last few decades, urban renewal policies have taken firm root in many Western European countries. The aim of these policies is often two-fold: one the one hand, they aim to improve the livability and reputation of deprived urban neighborhoods, often neighborhoods dominated by social housing and constructed in the 1960s and 1970s, and on the other hand they aim to improve the lives of the residents living in these neighborhoods (Manley et al., 2013). The content and implementation of urban renewal policies differ greatly between countries, depending on the welfare system and political forces as well as physical, social and economic structures of urban areas (Andersson \& Musterd, 2005). There are, however, also similarities between national urban renewal policies.

Most policies are strongly oriented towards altering the quality and composition of the housing stock of existing urban residential areas dominated by social housing (Kleinhans, 2004). In Europe, great importance is attached to creating a more diverse housing stock as a means to establish a more socially mixed neighborhood population (Manley et al., 2013). This diversification is established through the demolition, upgrading or sale of social rented housing and the construction of new, more costly owner-occupied or private rented housing. The result is more variation in housing sizes, forms, quality, prices, and above all a mix of tenures and therefore a more mixed (higher income) neighborhood population. Creating neighborhoods with a more balanced socio-economic mix of residents is a common strategy to tackle assumed negative neighborhood effects: the idea that living in deprived neighborhoods has a negative effect on residents' life chances over and above the effect of their individual characteristics (van Ham \& Manley, 2010). When deliberately mixing homeowners with social renters, the idea is that this will create a more diverse socioeconomic mix in neighborhoods, removing the potential of negative neighborhood effects (Musterd \& Andersson, 2005). It is assumed that in mixed neighborhoods there will be more positive role models and less negative peer group effects, and it is also assumed that the reputation of the neighborhood will improve when homeowners are introduced (Manley et al., 2013). Although the evidence that neighborhood effects are important and that areabased policies are effective is ambivalent (van Ham \& Manley, 2010; van Ham et al., 2012), mixed housing strategies are stated explicitly by many governments including those in the Netherlands, the United Kingdom, Germany, France, Finland and Sweden (Atkinson \& Kintrea, 2002; Kearns, 2002; Musterd, 2002; Veldboer et al., 2002).

By far the largest tenure mix operation in Europe is the Right to Buy (RTB) scheme in the United Kingdom. Since the 1970s, over 2.7 million socially rented houses have been sold, mainly to sitting tenants and with large discounts (Jones \& Murie, 2006). Selling these rented dwellings, and the resale of former socially rented dwellings by the RTB-owners has created mixed tenure neighborhoods because homeownership was introduced in neighborhoods previously dominated by social housing (Tunstall, 2011). According to Munro (2007: 247), "there can be no doubt that the Right to Buy represents one of the most significant housing policy measures in Britain of the last 25 years. It has achieved almost iconic status, representative of high Thatcherism; a key effort in the general drive for privatization, aimed both at rolling back the frontiers of the state and also in the creation of a "property owning democracy'. It has been instrumental in changing the aggregate tenure structure in Britain" (ibid.; see also King, 2010).

It is important to emphasize that, although creating mixed neighborhoods was not an explicit aim of the RTB policy, it was a side effect of the policy which was much welcomed by the government. In line with the privatization discourse, much research has been devoted to socioeconomic impacts of the RTB for tenant buyers. The RTB can be qualified as hugely 
successful in increasing access to homeownership (by house prices well below market value), by transferring wealth from the state to private households (substantial profits could be made through resales by capitalizing on the discount value and general house price increases), and by decreasing the stock of social housing (e.g. Jones \& Murie, 2006; King, 2010). These are undeniably good reasons for conservative politicians to celebrate the RTB and its outcomes, although critics have also identified many negative (side) effects of the RTB (see Jones \& Murie, 2006). However, there has been less attention focused on neighborhoods directly affected by the policy (Munro, 2007: 249). Based on a literature review, we synthesize the neighborhood outcomes of RTB: residualisation, neighborhood stability, tenure mix, social interactions, and dwelling maintenance. We will show that these outcomes are by no means solely beneficial.

In the next section, we introduce the Right to Buy policy and briefly account its history and policy development. Then, we turn to the literature review of the neighborhood outcomes of RTB. Finally, we present some conclusions.

\section{Right to Buy in the United Kingdom}

The Right to Buy (RTB) legislation was introduced in the 1980 Housing Act by Thatcher's Conservative Government elected in 1979. The legal RTB is one of the most significant transformations of the British housing market. Since it was introduced, over 2.7 million public sector dwellings have been sold to sitting tenants at prices well below market value, transferring wealth from the state to private households (Jones \& Murie, 2006). In the original RTB legislation, the discounts started at $33 \%$ and went up by $1 \%$ for each additional year of tenancy up to a maximum of $50 \%$ (Jones \& Murie, 2006). The primary reason for these sales was to stimulate homeownership and to respond to the desire of some tenants to own their properties (van Ham et al., 2012). The large volume of houses sold under the RTB since 1980 has dramatically altered the British housing market (Jones \& Murie, 2006) and has caused the distribution of dwellings by tenure to change radically (see Table 1 ).

Table 1 Tenure Distribution in England and Wales, 1981-2011, \%

\begin{tabular}{|l|l|l|l|}
\hline Housing Tenure & $\mathbf{1 9 8 1}$ & $\mathbf{2 0 0 1}$ & $\mathbf{2 0 1 1}$ \\
\hline Owner-occupied & 58 & 68 & 64 \\
\hline Social rented & 31 & 19 & 18 \\
\hline Private rented & 11 & 12 & 17 \\
\hline
\end{tabular}

These figures also show that the current economic crisis has caused the percentage of home-ownership to drop in recent years, and the percentage of private renting to increase. The most notable change was that since the early 1980s, the percentage of social housing has dropped from $31 \%$ to $18 \%$ in 2011 . Most of this change is due to the RTB.

The RTB initially gave only those living in council housing, i.e. social housing owned by local councils, the right to buy their dwelling. This right was later extended to tenants of other social landlords, such as housing associations. Over the years, changes in policies, and regional variations in the policies (including the rules and discounts) have incrementally introduced a high level of complexity into the RTB legislation (see Jones \& Murie, 2006 for an excellent overview). There have been large fluctuations and regional differences in the number of sales, with peaks in 1982 and 1989. Due to all the changes in the policy over time, and the regional differences in the RTB policy, it is not possible to speak of a 'single' Right to Buy policy. There are different rules in the four countries that make up the United Kingdom: England, Scotland, Wales and Northern Ireland. For example, in Scotland, it has been 
possible for some time for the Government to identify RTB exclusion zones in housing markets which are under pressure. Also, the Scottish government's 2010 Housing Act has ended the RTB for new tenants because of concerns over a shortage of rented affordable homes (Scottish Government, 2012). A recent consultation in Scotland showed that a majority of Scottish councils want the RTB for council and social housing to be scrapped completely (BBC News, 2012). In England new tenants can still execute their RTB.

The main objective of the RTB was to sell public housing and to stimulate private ownership. The RTB was seen as an end in itself, and not as a means to achieve any other housing or urban policy (Jones \& Murie, 2006). Also before the 1980 Housing Act local authorities were already selling dwellings. The main change the RTB legislation brought was that social housing tenants now had the right to buy their dwelling. Creating mixed tenure neighborhoods was never an explicit objective of the RTB legislation, but was later seen as a welcome side effect of the policy (Tunstall, 2011). The RTB has contributed greatly to the establishment of mixed (tenure) communities in the UK, but Tunstall (2011) points out that even before the RTB came into existence, very few neighborhoods were $100 \%$ mono-tenure (although this depends on the scale used, the larger the neighborhood, the more mixed).

Over the years, the RTB became a standard policy instrument in urban renewal programs to create mixed communities (Jones \& Brown, 2002). Urban renewal programs often consisted of selective demolition of social housing, estate redesign, improvements of existing housing stock, new construction and upgrading local facilities (Jones \& Murie, 2006). The idea was that this upgrading of neighborhoods would encourage existing residents to execute their RTB and purchase their rented houses, eventually leading to more mixed communities. The RTB had differential effects on tenure mix and social mix in various estates, an issue we will deal with extensively in the next section.

\section{Reviewing Neighborhood Outcomes of the Right to Buy}

In this section, we synthesize the outcomes of the RTB with regard to neighborhoods, based on a literature review. We deliberately exclude the voluminous literature which deals with the socioeconomic impacts for individual households who are tenant-buyers or households buying a former RTB dwelling that is sold on the private market (resales). We will extensively describe five types of neighborhood outcomes: residualisation, neighborhood stability, tenure mix and social mix, social interactions, and dwelling maintenance.

\section{Residualisation}

In the critical scientific discourse, the RTB has become most (in)famous for its residualisation effect on the social housing sector in the UK (Cole \& Furbey, 1994). The term residualisation broadly refers to two processes (see Burrows, 1999: 27-28). First, growing concentrations of the poorest and most disadvantaged households in the socially rented sector. Second, a shrinking social housing stock which increasingly consists of the lowest quality dwellings in the most deprived neighborhoods. Below, we analyze how residualisation arose through various processes in relation to the RTB.

The first and foremost question is: which households used their Right to Buy? Not surprisingly, these were generally the better-off, economically active tenants, with at least one income from paid employment, but often two earners in the household (Kerr 1988; Lynn 1991; Forrest \& Murie 1984a, 1984b; Jones \& Murie 2006; Munro, 2007; Van Ham et al. 2012). Tenant buyers also tended to be from higher social classes with white collar, skilled or semi-skilled occupations (Williams et al. 1987, cited in Van Ham et al. 2012). In terms of 
household features, most tenant buyers were middle- to old-aged married couples with nondependent children, especially during the early years of RTB (Forrest \& Murie 1988).

The second question is: what were the characteristics of the council dwellings sold under RTB? Generally, the more attractive properties in the most attractive neighborhoods were sold to sitting tenants. These were often larger single-family dwellings rather than flats (Dunn et al., 1987; Forrest \& Murie, 1990; Forrest et al., 1996; Foulis, 1985; Jones \& Murie, 1999: Scottish Executive, 2006). There is also a strong connection to the attractiveness of the area. The more desirable properties were often located in more desirable areas, in terms of residential environment and housing market position. Dunn, Forrest and Murie (1987) have shown that RTB sales have been highest in areas where owner occupation was already at high levels and where the initial stock of council housing was relatively small (see also Foulis, 1985; Jones \& Murie, 1999; Scottish Executive, 2006). "This systematically disproportionate sales pattern has left a council housing stock increasingly characterised by flats, nonconventional buildings and poorer quality neighbourhoods" (Munro, 2007: 249).

More fundamentally, the selective uptake of RTB by economically active households has resulted in a council sector with growing concentrations of economically inactive and poor residents, among which tenants with structural health problems or disabilities, single parents and elderly people (Forrest \& Murie, 1988). These residualisation forces, through changes in the council housing stock and its population, work in conjunction with the desirability of neighborhoods:

\begin{abstract}
"In urban areas the coincidence of Right to Buy sales and a period of widening social inequality has exacerbated the funneling of poorer sections of the community or marginalized groups into the least desirable estates. Obtaining a house in these neighbourhoods, whatever condition and quality, demonstrates some elements of social disadvantage by tenants. At the same time the changes in the characteristics of the council tenant population, encouraged by the Right to Buy siphoning off those with financial resources, has meant that the council housing stock is subject to higher turnover. The Right to Buy has therefore destabilised the remaining council housing stock and the least desirable estates in particular. This has inevitably increased social exclusion and economic marginalisation and reduced the sustainability of communities in these areas through the instability of local populations" (Jones \& Murie, 2006: 153).
\end{abstract}

The residualisation trends described above have another negative side effect. From the turn of the century, there has been an increasing focus on needs-based letting of social housing in the UK (Fitzpatrick \& Pawson, 2007). According to Munro (2007), this focus has meant that a greater proportion of new lettings have gone to those households with the greatest needs, such as homeless people (Fitzpatrick \& Pawson, 2007). Households now moving into the sector are less affluent than the out-movers, resulting in "social housing becoming more narrowly based socially and economically" (Burrows, 1999: 28, see also Forrest \& Murie, 1990; Power \& Tunstall, 1995). The combination of residualisation and needs-based letting contributed to "broader stigmatisation of socially rented housing, confirming its position as 'welfare' housing of last resort, only for those with no other options" (Munro, 2007: 249).

However, it would be incorrect to put the sole blame for residualisation at the RTB. For example, Burrows (1999: 27) has argued that the process of residualisation has not been due just to changes in the tenure of dwellings, but also due to the intensification of processes of residential movement by people which can be traced back to at least the mid1970s (Lee et al., 1995: 27). Munro (2007: 247) acknowledges that "the RTB did promote 
homeownership, which was already on an upward trajectory as a result of other factors". She not only refers to the dominant ideological discourse favoring homeownership, but also other programs, such as stock transfers to housing associations. Dunn et al. (1987: 58) have argued that:

"... There is a strong relationship between the pattern of sales under previous discretionary policies and the pattern under the Right to Buy. This calls into question the belief that the release of pent-up demand among previous nonsellers would be a significant element of Right to Buy sales. Rather, it seems that higher discounts, rising rents and other external factors related to the uneven impact of the recession [during the 1980s] and the movement of interest rates may have generated a new wave of sales in areas where many tenants had already bought. Whilst statutory compulsion to sell has accounted for a proportion of the very high levels of sales achieved over the last five years, it may be that the factors referred to above have been of greater significance."

Munro has also suggested that residualisation "would not have been so marked had there been a more significant level of investment in new, good quality social rented housing through the period of the RTB" (ibid., p. 258).

\section{Neighborhood stability}

It is argued that neighborhood stability, i.e. low levels of residential turnover, is supposed to benefit social interactions, social capital (DiPasquale \& Glaeser, 1999; Rohe et al., 2000) and trust in the neighborhood (McCabe 2012). The general premise is that raising levels of homeownership lowers residential turnover and thus increases stability in neighborhoods, which is good from the perspective of 'sustainable communities'. Jones and Murie (2006: 134) refer to the "wider received wisdom that sees the Right to Buy and the development of owner-occupation as increasing stability on estates and reducing the problems of economic and social inequality". Also:

"It has been argued that the key to sustainable communities is a stable population and housing opportunities that meet the needs of existing and future generations. The potential role of the Right to Buy in supporting this process is by meeting the increasing aspirations of households to buy a home in their local communities either immediately or subsequently through resales. However, there are counter concerns that the impact of sales may destabilise areas via the introduction of new households from outside of the area and the operation of market forces." (ibid.: 141).

Hence, the relationship between neighborhood stability and increasing levels of homeownership through the RTB is far from straightforward. We will discuss five issues which are related to neighborhood stability. The first issue concerns the factor time: stability in the short term, i.e. directly after a wave of RTB sales to sitting tenants, and stability in the longer term, depending on resales of RTB-dwellings by former tenant buyers. Jones and Murie (2006: 141) explain that:

"At first the Right to Buy probably had little influence on these areas as the initial group of purchasers did not generally buy with a speculative intent but intended to stay in their home for the rest of their lives. However, [...] this 
changed in the 1990s as resales began. In the subsequent decade resales became established as properties offering good value for money and in particular took on a role in the wider local housing market as starter homes or homes for households at the beginning of the family cycle."

According to Van Ham et al. 2012, the initial stability of RTB neighborhoods is easy to explain as "almost half of the buyers had been tenants for 20 years or more and previous moves within the council sector had allowed them to secure relatively desirable dwellings. Few of these initial RTB purchasers stated that they wished to move on in the near future and many expected to stay in their house for the rest of their lives (Forrest \& Murie 1984a, 1984b; Foulis 1985)." Hence, in the initial stages of the RTB, stability is mostly associated with sitting tenant buyers who do not affect turnover positively or negatively, regardless of tenure.

A second and related issue concerns market forces, especially the wider housing market context. In the previous subsection on residualisation, we established the selective sales patterns of tenants taking up the RTB. The more desirable properties were often located in more desirable areas with a strong housing market position. Consequently, RTB sales have been highest in attractive areas where owner occupation was already at relatively high levels and where the initial stock of council housing was smaller. Thus, market forces already played a role in the initial take-up rates of the RTB by tenants.

Subsequently, the influence of market forces increased when resales started to occur, as RTB-owners offered their dwellings for sale on the housing market. There are large variations in how former RTB dwellings became a part of the market for owner-occupied housing (Forrest et al., 1996). Munro (2007: 25) has mentioned that "the extent to which excouncil houses are integrated into the general market for owner-occupied housing depends critically on the location of the dwelling, with those in more pressured housing markets, particularly in the South East of England becoming part of the mainstream housing market relatively quickly, while those in less pressured markets can remain more distinct from mainstream owner occupation for longer (Forrest et al., 1996; Pawson \& Watkins, 1998)". These mechanisms can work out negatively for neighborhood stability both in desirable and undesirable areas. The less desirable areas have lower RTB sales rates and may therefore become even more exposed to high turnover of lettings and the process of residualisation (Jones \& Murie, 2006: 141). However, in desirable estates or neighborhoods, "the market segment [...] may provide a stable, long term housing resource through the development of sustainable resale markets, but these market segments could become increasingly transitional because of their role within the wider local housing market. For example, an area becomes a locus for low income owner-occupiers and the once stable desirable council estate becomes a neighbourhood suffering from high levels of mortgage foreclosure, high sales turnover and an increase in private tenancy" (ibid.). We will return to the issue of private tenancy.

Overall, the size of the social housing sector has decreased significantly, but this did not necessarily apply to demand for social housing. Consequently, waiting lists grew longer, which made it even more difficult to enter social housing (e.g. Burrows, 1999; Forrest \& Murie, 1988; Pawson \& Bramley, 2000; Scottish Government, 2012). Research by Holt Brook et al. (2006) has shown that particularly tenants have reported reduced access for other tenants to perceived 'good' or 'stable' neighborhoods. Importantly, the issue of reduced access does not apply to social housing only. Jones and Murie (2006: 143) have shown that resales offer good value for money within local housing markets, which attracted buyers from beyond the community, outbidding local residents. This occurred for instance in tourist areas where resales became second homes or retirement homes (Williams \& Twine, 1994). 
The third issue concerning the links between neighborhood stability and the RTB is selection. Neighborhood stability may not be primarily the consequence of homeownership, but might also be its cause. This is counterintuitive to the common wisdom of stabilization by homeownership. This 'reversed' mechanism' seems to operate in various ways in the context of the RTB. In particular, Jones and Murie (1999) have provided an analysis of the RTB impacts on stability of neighborhoods by looking more in-depth at the situation in Glasgow and Birmingham. Their analyses indeed revealed that residential turnover was lower on council housing estates with higher RTB sales levels. However, their data did not show that high levels of sales subsequently resulted into lower turnover rates. Jones and Murie concluded that the council estates with high levels of sales were likely to be the more stable estates with lower levels of turnover prior to the Right to Buy. Seven years on, they concluded that:

"The evidence from Glasgow and Birmingham is, judging by the stability measures, that [...] the previous social standings of neighbourhoods remain broadly stationary. The most desirable areas continue to have the lowest level of turnover in their rented sectors and attract the highest level of sales and resales." (Jones \& Murie, 2006: 154).

Van Ham et al. (2012) have suggested that selective sorting into the RTB program (i.e. tenants intending to stay as long as possible), might cause those who bought their dwelling to be the least mobile. From this perspective, not the dwelling purchase itself caused neighborhood stability, but the fact that the purchase is the result of a strong preference for staying put (see also King, 2010: 70).

A fourth issue is that RTB-owners may want to move on again after a while, in order to trade-up in the market for owner-occupied housing. In their recent investigation of the moving behavior of Right to Buy owners in the UK, Van Ham and colleagues (2012) showed that this appears not a strong factor. They found that the probability of a RTB-owner making a long distance move falls between that of social renters and traditional owner occupiers. The difference between RTB-owners and homeowners or social renters was not significant in their analysis. "So after buying their house, RTB-owners showed more resemblance with the group they joined (homeowners) than the group they had departed (social renters)" (Van Ham et al. 2012; 14). However, RTB-owners are less satisfied with their dwelling than traditional owners, but more satisfied than those in social housing. And RTB-owners are the most likely to state that their neighborhood is the reason they want to move, closely followed by social renters (Van Ham et al., 2009).

There is a fifth way in which ownership acquired through the RTB may negatively affect neighborhood stability. That is when, for various reasons, the RTB translates into higher levels of private tenancy. One reason is that "RTB purchasers move on, but let out their properties directly, again frustrating the objective of increasing local homeownership rates, potentially facilitating lettings to undesirable tenants and probably, also, creating landlords with little capacity or perhaps enthusiasm to invest in the maintenance of the property" (Munro, 2007: 253). The second and connected reason is that private tenants are generally very mobile and create a relatively high turnover.

\section{Tenure mix and social mix}

In the Introduction, we stated that creating mixed neighborhoods (through changes in housing tenure and socioeconomic composition of the population) was not an explicit aim of the RTB policy, although it was welcomed as a side effect by the government (Tunstall, 
2011). At first sight, selling homes to tenant purchasers seems a straightforward instrument to create mixed neighborhoods. However, there are three issues which refute a simple causal pathway between RTB and social mix. Firstly, the RTB did initially not alter the social mix in council housing areas, as sitting tenants purchased their dwellings. Hence, initial RTB take-up by tenants only changed the tenure balance, with the more affluent council tenants selecting into owner-occupation. Only when RTB properties were resold on the open market, subsequent purchasers changed the socioeconomic and demographic profiles of the local community (Jones \& Murie, 2006: 133). The nature of that socioeconomic change was dependent on various factors, of which the market potential of RTB dwellings and their neighborhoods (see also previous subsection) is an important one. Offering former RTB dwellings on the open housing market tapped a wide potential of buyers:

"Survey evidence shows that the resale market is not predominantly a first-timebuyer market. Half of those who have purchased former public sector dwellings were already owner-occupiers at the time. For most of those concerned, buying an ex-RTB property presented an opportunity to trade up in the market in terms of size and type. Nevertheless, for a considerable proportion of first-time buyers, the availability of a former public sector property may have been crucial in facilitating access to home-ownership. Significantly, one-third of this group had previously contemplated social renting" (Pawson \& Watkins, 1998: 1291; see also Forrest et al., 1996).

Other studies of resale purchasers have shown that the majority of moves were over short distances (e.g. Pawson et al., 1997). The above suggests various pull factors connected to stages in housing careers. Buyers of former RTB-dwellings who had previously contemplated social renting, are unlikely to have significantly higher incomes than many council tenants.

Secondly, the RTB has sometimes translated into higher levels of private tenancy instead of more owner-occupation (see previous subsection). From this point of view, tenure mix has indeed increased, but not in coherence with policy hopes and expectations. According to the Scottish Executive (2006: 59), "some of the research on mixed communities had identified that tenure mix cannot guarantee particular types of mix in the longer term." Especially the growth of private renting lowers the ability to control the profile of areas:

"Whilst communities being newly built would expect to contain a balanced mix of tenure, the Right to Buy mixes tenures in a more random manner. The Right to Buy is a rather blunt tool for mixing communities in this respect [...]. It is also worth bearing in mind that it is not possible to control the movement of former Right to Buy properties into the private rented sector, and that - without applying rights of pre-emption or housing burdens - this is true for all developments, whether old or new" (Scottish Executive, 2006: 58).

Finally, there is the ambivalent nature of the policy assumptions. Munro (2007: 252) has pointed out the dichotomous attitude when considering the role of owner-occupiers in estates that were previously predominantly rented. "On the one hand there is a clear policy focus on tenure mix as a positive measure towards creating mixed and sustainable communities, especially where otherwise such communities would be dominated by disadvantaged households (Atkinson \& Kintrea, 2002). However, in other circumstances, owners in such estates are seen as rather problematic, especially where they may contribute 
to increased turnover and instability, or where low income or reluctance impedes participation in, and the progress of, landlord led physical refurbishment" (ibid.).

\section{Social mix and social interactions}

As mentioned above, the RTB did initially not alter the social mix in council housing areas, as sitting tenants purchased their dwellings. However, when resales started to occur, relatively young people, often in white collar occupations, moved into neighborhoods which were previously dominated by social housing tenants. This is where the existing social mix became more dynamic. The contrast between the newcomers buying former RTB dwellings and original council tenants, who were often on social benefits, has regularly resulted in social tensions (Jones \& Murie, 2006). Research by Holt Brook et al. (2006) indicated that both sitting tenants and Right to Buy buyers hade widely varying perceptions of the impact of the RTB on neighborhoods. The most common view was that new owners generally took greater care of their properties than tenants. However, while some respondents reported that owners also were 'better and more involved neighbors', others claimed that owners were more selfish and less concerned about the neighborhood.

This topic relates to a wider field of study i.e. benefit of mixed communities in terms of social interaction between residents from different tenures (for an extensive overview of associated issues and mechanisms, see Kleinhans, 2004: 377-380). A systematic review of this subject has shown that the evidence is either limited or negative (Bond et al., 2011). Increased 'exposure' between residents with different values and lifestyles (e.g. social renter and owner-occupiers) is a common cause of tensions. In the context of the RTB, much evidence points at either 'peaceful indifference' or tensions between residents of different tenures e.g. (Beekman et al., 2001; Kleinhans, 2004). Compared to new residential areas or demolition combined with replacement of new units, the RTB provided a tenure mix strategy which did not by definition introduce 'new faces' in neighborhoods. "Far greater levels of cross-tenure networks are to be found where owner-occupation has arisen in a more organic way as a result of tenants exercising their Right to Buy" (Beekman et al., 2001: 59). Related is the finding that "residents in a case study area where mixed tenure had been achieved through RTB had more difficulty in distinguishing the tenure of their neighbours than residents in other case study areas" (Scottish Executive, 2006: 59). The fact that RTB did often not result in stinking visual differences between tenures, decreased the opportunity to interpret tenure as a visible marker of the social status of residents.

Several social implications of mixed tenure relate to inter-tenure attitudes and perceptions on levels of maintenance (see next subsection). However, residents' expected length of residence is an important factor determining their attachment to and involvement in the neighborhood. Jones and Murie (2006) further observed that buy-to-let practices of former RTB dwellings can lead to further instability and tensions:

\footnotetext{
"The social glue of these neighbourhoods is potentially further undermined by the introduction of private tenants. [We] demonstrated how in these undesirable areas Right to Buy resale markets are weak and many of the resales have been bought up by landlords. This brings with it more instability as private tenants tend to be very mobile, as noted“ (Jones \& Murie, 2006: 149).
}

The higher mobility of private renters is associated with a lower attachment to the areas, as they know they will move on sooner than later. Whereas both owners and social renters may feel a certain ownership of and responsibility for their neighborhood, this may apply much less to private landlords and private renters who usually have different interests and 
are less bothered by the social climate in the neighborhood. One of the issues where this difference is felt most keenly, is dwelling maintenance.

\title{
Homeowner and landlord maintenance
}

The literature on benefits of homeownership emphasizes that owners have a financial stake in the condition and maintenance of their dwelling and are, mutatis mutandis, more willing than renters to ensure that maintenance is up to standards (e.g. DiPasquale \& Glaeser, 1999; Rohe et al., 2000). Whereas this line of thinking has received much criticism, also in the context of the RTB, it makes sense in the perception of both tenants and tenant buyers in RTB areas. Research by Holt Brook and colleagues (2006) showed a common view that owners generally took greater care of their properties than tenants and that this also encouraged other residents to take more pride in their dwellings.

However, reality is harsher with respect to dwelling upkeep by tenant buyers or consecutive buyers. Tenant buyers with low incomes often struggled with maintenance costs, which were higher than expected, of single-family dwellings. Other dwelling types implied additional complications connected to multi-owner settings:

\begin{abstract}
"Evidence concerning the impact of the Right to Buy on the physical quality of dwellings and neighbourhoods is mixed and somewhat partial. There is no doubt that some owners in nonconventional properties have found high service costs hard to afford, and especially in high-rise flats owners have, on occasion, faced bills greater than the estimated value of their home (although local authorities can buy back properties in such situations)" (Munro, 2007:252).
\end{abstract}

The specific context of the RTB causes a potential problem which transcends the investment capacity of individual tenant buyers. As the RTB uptake could differ from door to door (within apartment blocks), mixed tenure implied mixed ownership on block level with profound legal and financial consequences for the maintenance of collective parts, such as roofs and stairways. Local authorities and other landlords had to deal with individual owners in arranging part of the maintenance, tackling owners' financial inability or reluctance (or both) to let them contribute their share of the maintenance or improvement costs.

In this respect, Leather and Anderson (1999) found a whole range of practices amongst local authorities and other landlords. Various arrangements were also enforced (by local authorities upon individual owners) to a different extent, so that there is no clear picture of the effectiveness of multi-owner maintenance arrangements. Obviously, negotiations between landlords and individual owners regularly resulted in disagreements about the required repair and maintenance standards. Part of the disagreements is associated with a perceived lack of information. "Research found mixed practice amongst local authorities in respect of the amount of information supplied to tenants concerning their common repair responsibilities, with many respondents indicating that the only information provided was in the title deeds" (Russell \& Welsh, 1998, cited in Scottish Executive, 2006: 56).

As problems already appeared following the initial uptake of the RTB by tenant purchasers, matters became worse with resales. According to Scott and colleagues (2001), new owners of resold Right to Buy dwellings properties were often not aware of the impending costs, burdens and legal obligations associated with the previous council housing, and did not take this adequately into consideration when buying the property.

From the turn of the century onwards, the above problems have also affected efforts to regenerate council housing areas by large-scale renovation. Thus, various actors involved 
in such planned renovation efforts "increasingly have to face the difficulties of ensuring that owner occupied houses are brought up to similar repair and environmental standards as those in the social rented sector, and of ensuring that the very existence of owners does not delay or prevent improvement being realized" (Craigforth, 2002: 9).

There is also a time-lagged effect connected to maintenance. In general, many tenant purchasers in the early years of the RTB made several improvements to their dwellings, on top of maintenance. Leather (2000) has pointed out that refurbishments made by new RTB owners in the early years of the policy are now approximately 25 years old and may require further investment by their ageing owners. In the light of the continuing economic crisis, especially these owners may face severe financial constraints that hinder them making the necessary investments to maintain and update these improvements (see also Munro, 2007).

Hitherto, we have analyzed knowledge about impacts on maintenance after council housing has been sold. The qualitative research of James, Jordan and Kay (1999) shows a particularly interesting reversal of the sequence of these events. A substantial part of their interview respondents involved relatively poor council tenants who used their unemployed status as an opportunity for increased dwelling improvement activity. For some of them, an improvement in employment status (and disposable income) triggered the decision to buy "in order to protect their work investment, and to secure their stake in the local (valued) community. This in turn leads to a desire for further home improvements, and a recognition of the need to increase or make more reliable their household earnings from employment" (ibid.: 36). The authors also conclude that these tenants decided to buy "as a way of securing their future in the area and controlling their personal environment, rather than as an escape from a residual 'ghetto' of welfare housing" (ibid: 27).

\section{Conclusions}

In this paper we set out to synthesize the neighborhood outcomes of the Right to Buy (RTB) policy in the United Kingdom, which is the largest (originally unintended) tenure mix program in Europe. The RTB never had mixing as an explicit policy aim, but over time the RTB became part of mainstream urban renewal policies aiming to establish more socially mixed neighborhoods. There is consensus about the RTB being a success in terms of facilitating access to homeownership for working-class households. Large transfers of wealth from the state to private households occurred through the discounts on market values and the sometimes huge profits made by resales of RTB properties by tenant buyers.

However, the RTB had a double edged effect on social mixing. One the one hand, the RTB caused social housing in the UK to become residualized. The most desirable dwellings in the best neighborhoods were sold first, leading to higher levels of concentrated poverty in the least desirable neighborhoods. On the other hand, the most desirable neighborhoods with already relatively high levels of homeownership and more affluent households witnessed a further increase in homeownership. Between these ends, some neighborhoods saw an increase in ownership that was not matched by owner-occupation because dwellings were resold on the buy-to-let market and ended up in the private rented sector.

Contrary to common wisdom of positive effects from homeownership, the RTB has had various impacts on the stability of neighborhoods. "The evidence broadly suggests that the impact of Right to Buy on individual neighbourhoods is linked to issues of stability and demand that existed prior to Right to Buy, with Right to Buy reinforcing existing neighbourhood trends. Initially stable, high-demand neighbourhoods have seen high levels of Right to Buy sales. Low demand areas on the other hand have seen reduced levels of 
sales." (Scottish Executive, 2006: 60). To a large extent, the impacts for individual neighbourhoods were contingent upon the wider housing market context, which strongly determined both the initial take-up rates as well as the extent to which former RTB dwellings integrated through resales into the broader market of owner-occupied housing.

Especially resales have affected social mix in neighborhoods, by enabling socioeconomically different households to enter the areas formerly dominated by council tenants, of whom many had a low income and/or were living on social benefits. The lifestyle differences introduced by these residential moves created either 'peaceful indifference' or tensions and conflicts between renters and owners, although the RTB is clearly a "more organic way [of mixing]" (Beekman et al., 2001: 59) than tenure mix in new developments or neighborhoods subject to demolition and new construction.

Finally, the RTB created various complexities regarding dwelling maintenance. Although there is evidence for owners taking greater care of their properties than tenants, new owners with relatively low incomes often struggled with maintenance costs. RTB also introduced mixed ownership on block level, requiring local councils, landlords and individual owners to negotiate about the nature, quality and costs of maintenance. This has also affected efforts to regenerate social housing areas with individual RTB owner by means of large-scale regeneration.

It can be concluded that the RTB had major impacts on neighborhoods and local communities. Impacts which were not always positive. The Scottish Executive (2006: 58) called the RTB a blunt tool for mixing communities, with no control over the outcomes and with more or less random effects on neighborhoods. Other countries, such as the Netherlands, are now considering to introduce the RTB in the social housing sector. When introducing the RTB, we call for policies to be developed with the UK experiences in mind. Targeting the RTB at only specific types of properties, in specific locations, possibly by using RTB exclusion zones, can help to avoid the development of residualized communities.

Acknowledgements: Part of the project on which this paper is based was funded by the Kenniswerkplaats Leefbare Wijken, in Rotterdam.

\section{References}

Andersson, R. \& Musterd, S. (2005) Area-based policies: A critical appraisal. Tijdschrift voor Economische en Sociale Geografie, 96(4), 377-389.

Atkinson, R. \& Kintrea, K.(2002) Area effects: what do they mean for British housing and regeneration policy? European Journal of Housing Policy, 2, 147-166.

Beekman, T., Lyons, F. \& Scott, J. (2001) Improving the Understanding of the Influence of OwnerOccupiers in Mixed Tenure Neighbourhoods. Edinburgh: Scottish Homes.

Bond, L., Sautkina, E. \& Kearns, A. (2011) Mixed Messages about Mixed Tenure: Do Reviews Tell the Real Story? Housing Studies, 26(1), 69-94.

Brounen, D., Cox, R. \& Neuteboom, P. (2012) Safe and Satisfied? External Effects of Home-ownership in Rotterdam. Urban Studies, 49(12), 2669-2691.

Burrows, R. (1999) Residential Mobility and Residualisation in Social Housing in England. Journal of Social Policy, 28(1), 27-52.

Cole, I. \& Furbey, R. (1994) The Eclipse of Council Housing. London: Routledge.

Craigforth (2002) Engaging Owners in Mixed Tenure Neighbourhoods. Edinburgh: Chartered Institute of Housing.

Dunn, R., Forrest, R. \& Murie, A. (1987) The Geography of Council House Sales in England 1979-1985. Urban Studies, 24, 47-59. 
Fitzpatrick, S. \& Pawson, H. (2007) Welfare Safety Net or Tenure of Choice? The Dilemma Facing Social Housing Policy in England. Housing Studies, 22(2), 163-182.

Forrest, R. \& Murie, A. (1984a) Right to Buy? Issues of Need, Equity and Polarisation in the Sale of Council Houses. Working Paper No. 39. Bristol: School for Advanced Urban Studies, University of Bristol.

Forrest, R. \& Murie, A. (1984b). Monitoring the Right to Buy. Bristol: School for Advanced Urban Studies, University of Bristol.

Forrest, R. \& Murie, A. (1988) Selling the Welfare State: The Privatisation of Public Housing. London: Routledge.

Forrest, R. \& Murie, A. (1990) Residualisation and council housing: A statistical update. Bristol: School for Advanced Urban Studies, University of Bristol.

Forrest, R., Gordon, D. \& Murie, A. (1996) The position of former council homes in the housing market. Urban Studies, 33(1), 125-136.

Foulis, M. (1985) Council house sales in Scotland. Scottish Office: Edinburgh.

Guardian (2012) Councils back end of right to buy housing policy. 16 November 2012.

Ham M. van \& Manley D. (2010) The effect of neighbourhood housing tenure mix on labour market outcomes: a longitudinal investigation of neighbourhood effects. Journal of Economic Geography, 10, 257-282.

Ham, M. van et al. (2009) Right to Buy... time to move? Non-Technical Summary (Research summary) ESRC End of Award Report, RES-000-22-2460. Swindon: ESRC.

Ham, M. van, Williamson, L., Feijten, P. \& Boyle, P. (2012) Right to buy ... time to move? Investigating the moving behaviour of right to buy owners in the UK. Journal of Housing and the Built Environment, DOI 10.1007/s10901-012-9296-3

Holmes, C. (2006) Mixed Communities: Success and Sustainability, JRF Foundations, Ref 0176. York: Joseph Rowntree Foundation.

Holt Brook, J., Kinver, A. \& Strachan, V. (2006) Views and Experiences of the Right to Buy Amongst Tenants and Purchasers. Edinburgh: Scottish Executive.

James, S., Jordan, B. \& Kay, H. (2001) Poor People, Council Housing and the Right to Buy. Journal of Social Policy, 20(1), 27-40.

Jones, C. \& Brown, J. (2001) The establishment of markets for owner occupation within public sector communities. European Journal of Housing Policy, 2(3), 265-292.

Jones, C. \& Murie, A. (1999) Reviewing the Right to Buy. Centre for Urban and Regional Studies. Birmingham: University of Birmingham.

Jones, C. \& Murie, A. (2006) The Right to Buy: Analysis \& Evaluation of a Housing Policy. Oxford: Blackwell Publishing Ltd.

Kearns, A. (2002) Response: from residential disadvantage to opportunity? Reflections on British and European policy research. Housing Studies, 17, 145-150.

Kerr, M. (1988) The Right to Buy: A national survey of tenants and buyers of former council houses. London: HMSO.

Kleinhans, R. (2004) Social implications of housing diversification in urban renewal: a review of recent literature. Journal of Housing and the Built Environment, 19(4), 367-390.

King, P. (2010) Housing Policy Transformed: The right to buy and the desire to own. Bristol: The Policy Press.

Leather, P. \& Anderson, K. (1999) The Condition of Former Right to Buy Properties and Innovative Approaches to the Management and Financing of Repair Work, Report to Scottish Homes (Report 74). Edinburgh: Scottish Homes.

Leather, P. (2000) Crumbling Castles? Helping Owners to Repair and Maintain their Homes. York: Joseph Rowntree Foundation.

Lee, P., Murie, A., Marsh, A. \& Riseborough, M. (1995) The Price of Social Exclusion. London: Natural Federation of Housing Association.

Lynn, P. (1991) The Right to Buy: A national follow-up survey of tenants of council homes in England. London: HSMO. 
Manley D., van Ham M., Bailey N., Simpson L. \& Maclennan D. (Eds.) (2013) Neighbourhood Effects or Neighbourhood Based Problems? A Policy Context. Springer: Dordrecht.

McCabe, B. (2012) Homeownership and Social Trust in Neighbors. City \& Community, 11(4), 389-408.

Munro, M. (2007) Evaluating Policy Towards Increasing Owner Occupation. Housing Studies, 22(2), 243-260.

Musterd, S. (2002) Response: mixed housing policy: a European (Dutch) perspective. Housing Studies, 17, 139-143.

Musterd, S. \& Andersson, R. (2005) Housing mix, social mix and social opportunities. Urban Affairs Review, 40, 761-790.

Pawson, H. \& Watkins, C. (1998) The Position and Role of Former Public Sector Homes in the Owneroccupied Sector: New Evidence from the Scottish Housing Market. Urban Studies, 35(8), 12911309.

Power, A. \& Tunstall, R. (1995) Swimming Against the Tide: Polarisation or Progress on 20 Unpopular Council Estates, 1980-1995. York: Joseph Rowntree Foundation.

Rohe, W., McCarthy, G. \& Van Zandt, S. (2000) The social benefits and costs of homeownership. Washington, DC: Research Institute for Housing America.

Russell, F. \& Welsh, J. (1998) Factors in Common: How Local Authorities Manage Common Repairs to Property in Mixed Ownership in Scotland. Glasgow: Scottish Consumer Council.

Scott, S., Currie, H., Dean, J. \& Kintrea, K. (2001) Good Practice in Housing Management: Case Studies, Conclusions and Recommendations. Edinburgh, Scottish Executive.

Scottish Executive (2006) The Right to Buy in Scotland - Pulling Together the Evidence. A Report to Parliament on the Effect of the Right to Buy in Practice. Edinburgh: Scottish Executive.

Scottish Government (2012) The Scottish Government 2012 Right to Buy Guide. Available from http://www.scotland.gov.uk/Topics/Built-Environment/Housing/16342/rtb (Last accessed on January $\left.17^{\text {th }}, 2013\right)$.

Tunstall, R. (2011) How much tenure mix is there in England, how has this changed 1981-2001 and what are the policy implications? Paper presented at the $23^{\text {rd }}$ ENHR Conference 'Mixité' : an urban and housing issue?', Toulouse (France), 5-8 July 2011.

Available from http://www.enhr2011.com/sites/default/files/Tunstall-WS03.pdf (Last accessed on January $\left.17^{\text {th }}, 2013\right)$.

Veldboer, L., Kleinhans, R. \& Duyvendak, J.W.(2002) The Diversified Neighbourhood: An International Perspective: How do countries deal with the spatial distribution of economic and cultural differences? Journal of International Migration and Integration, 3(1), 41-64.

Williams, N. \& Sewel, J. (1987) Council house sales in the rural environment. In: B. D. McGregor, D. S. Robertson \& A. Shucksmith (Eds.) Rural housing in Scotland: Recent research and policy. Aberdeen: Aberdeen University Press.

Williams, N. \& Twine, F. (1994) Locals, incomers and second homes: the role of resold public sector dwellings in rural Scotland. Scandinavian Housing and Planning Research, 11, 193-209. 